\title{
Dexamethasone treatment of lipopolysaccharide-induced meningitis in rabbits that mimics magnification of inflammation following antibiotic therapy
}

\author{
P. ROONEY, G. BILBE* O. ZAK* and T. O'REILLY*ं \\ Ceredigion Health Unit, Bronglais General Hospital, Aberystwyth, Dyfed, Wales and * Pharma Research, \\ Ciba-Geigy Ltd, Basel, Switzerland CH-4002
}

\begin{abstract}
Summary. The objective of adjunct anti-inflammatory therapy of bacterial meningitis is the containment of heightened inflammation caused by lysis of bacteria by antibiotics. This can be modelled by giving two consecutive intra-cisternal injections of lipopolysaccharide (LPS) to rabbits, the first at $0 \mathrm{~h}$ to induce inflammation to mimic that occurring during the proliferation of bacteria in the cerebrospinal fluid (CSF), and the second at $6 \mathrm{~h}$ to mimic inflammation subsequent to antibiotic-induced bacterial lysis. Injection of $2.5 \mathrm{ng}$ of LPS induced pleocytosis at $4 \mathrm{~h}$ which was preceded by a peak of tumour necrosis factor (TNF) activity at $2 \mathrm{~h}$. A subsequent injection of $25 \mathrm{ng}$ of LPS at $6 \mathrm{~h}$ induced second peaks of pleocytosis and CSF TNF. Dexamethasone $(1.5 \mathrm{mg} / \mathrm{kg}$, i.v.) administered $15 \mathrm{~min}$ or $1 \mathrm{~h}$ before the second injection of LPS tended only to reduce CSF TNF, but effectively prohibited further pleocytosis. Brain TNF $\alpha$ mRNA levels were unchanged at 6 and $7 \mathrm{~h}$ after LPS injection, and were unaffected by dexamethasone. These results indicate that the subarachnoid space is distinct from the general circulation in that the TNF-producing cells present do not display a hypo-responsive state towards LPS as occurs when LPS is injected systemically. Furthermore, dexamethasone is able to attenuate the secondary inflammatory response resulting from a second LPS injection without eliminating a second peak of TNF activity.
\end{abstract}

\section{Introduction}

Bacterial meningitis is accompanied by an intense inflammatory response in the subarachnoid space that is apparently exacerbated by the use of lytic antibiotics. ${ }^{1}$ The inflammatory reaction is initiated by bacterial components (peptidoglycan; lipopolysaccharide: LPS), is mediated by cytokines (e.g., interleukin-1: IL-1; tumour necrosis factor: TNF) ${ }^{1}$ and the extent of subarachnoid space inflammation has been correlated to the development of neurological sequelae. ${ }^{1-7}$ Extensive experimental studies ${ }^{1}$ have focused on reducing the inflammatory response by the use of anti-inflammatory agents, usually dexamethasone, and have led to the evaluation of dexamethasone in clinical trials. $^{8-12}$ Although these trials have demonstrated the benefit of supplemental anti-inflammatory therapy in the reduction of cerebrospinal fluid (CSF) cellular and cytokine levels thought to be involved in

Received 31 July 1994; revised version accepted 30 Dec. 1994 Presented in part at the 18th International Congress of Chemotherapy, Stockholm, Sweden.

+ Correspondence should be sent to Dr T. O'Reilly. brain damage, with a subsequent reduction in neurologic sequelae, ${ }^{2,5-7}$ these results have not been considered unequivocal. ${ }^{13-21}$

The progression of the inflammatory response in bacterial meningitis can be considered to be a twostage process: the first stage occurs during the proliferation of the micro-organism within the subarachnoid space, and in the second stage rapid release of bacterial wall fragments following antibiotic therapy magnifies the inflammatory response. ${ }^{1}$ From a clinical point of view, the earliest opportunity to give patients anti-inflammatory therapy in an attempt to contain this second inflammatory cascade is just before the administration of antibiotics. ${ }^{9}$ Administration of dexamethasone before ceftriaxone has been judged to give better clinical results ${ }^{9}$ than dexamethasone administration after antibiotics. ${ }^{11.12}$

A possible factor complicating the interpretation of the available experimental and clinical data stems from the observation that in rabbits a hyporesponsive state is induced for the release of TNF into the bloodstream in response to a second systemic injection of LPS. ${ }^{22}$ What is as yet unclear is whether the subarachnoid space can also become refractory to 
LPS, and whether the enhanced pleocytosis proposed to occur after antibiotic treatment is delayed until recovery from this hyporesponsive state. If this hyporesponsive state exists. then the effects of dexamethasone at early stages of treatment may be unclear.

Therefore, the aim of the present study was to determine whether the subarachnoid space displays evidence of becoming hyporesponsive to LPS and to evaluate the early effects of dexamethasone as an adjunct treatment. A two-stage model of subarachnoid inflammation was used in an attempt to reproduce the sequence of pathophysiological events that occur in antibiotic-treated meningitis. After the establishment of subarachnoid space inflammation in rabbits by the intra-cisternal injection of LPS to mimic the inflammation existing at clinical presentation, dexamethasone or saline was given before a second injection of LPS. which was designed to mimic the antibioticinduced release of cell wall fragments. The capacity of dexamethasone to alter CSF leucocyte and TNF levels, and to alter the levels of brain mRNA specific for TNF $\alpha$, was then determined.

\section{Materials and methods}

\section{Sterile meningitis model}

The experimental protocols were approved by the ethical committee of the Kantonales Veterinäramt of Basel Stadt. On the basis of a previous study, ${ }^{23}$ a sterile LPS-induced meningitis was established in rabbits by the use of Escherichia coli LPS (O111:B4, Sigma). Specific-pathogen-free chinchilla rabbits, $2 \cdot 5-3 \mathrm{~kg}$ in weight, were obtained from Thomae, Biberach an der Riss, Germany. On the day before an experiment, rabbits were anaesthetised with a combination of fentanyl and fluanisone (Hypnorm, Janssen) and were then fitted with prosthesis to facilitate subsequent placement within a stereotactic frame according to an established method. ${ }^{24}$ Before the induction of meningitis, rabbits received ethyl carbamate (urethane) $1.75 \mathrm{~g} / \mathrm{kg}$ subcutaneously (s.c.) and then pentobarbital $10 \mathrm{mg} / \mathrm{kg}$ intravenously (i.v.) to induce deep, long-term anaesthesia. The animals were fixed in the stereotactic frame. and 3.5-inch spinal needles $(25 \mathrm{~g})$ were sited in the cisterna magna to allow repeated sampling of CSF. After the withdrawal of $0.4 \mathrm{ml}$ of CSF, $2.5 \mathrm{ng}$ of LPS (diluted in $0.2 \mathrm{ml}$ of pyrogen-free physiological saline) was introduced into the subarachnoid space and the needle was flushed with $0.1 \mathrm{ml}$ of CSF. CSF $(0.2 \mathrm{ml})$ was sampled at 2 and $4 \mathrm{~h}$ after injection. At $5.75 \mathrm{~h}$ after the initial LPS injection. animals received dexamethasone (Decadron, Merck Sharp and Dome) $1.5 \mathrm{mg} / \mathrm{kg}$, i.v., and controls received saline. Dexamethasone was diluted in pyrogen-free physiological saline so that rabbits received $1 \mathrm{ml} / \mathrm{kg}$ i.v. boluses delivered over $3-5 \mathrm{~min}$. At $6 \mathrm{~h}, 0.3 \mathrm{ml}$ of CSF was removed and $25 \mathrm{ng}$ of LPS were injected in a $0 \cdot 2-\mathrm{ml}$ volume, and $0.1 \mathrm{ml}$ of CSF was used to flush the needle. CSF samples were obtained subsequently at 8,10 and $12 \mathrm{~h}$ after the initial dose of LPS. The rate of removal of CSF did not exceed the rate of CSF formation $\left(c .0 .4 \mathrm{ml} / \mathrm{h}^{25}\right)$. At $12 \mathrm{~h}$ after the initial administration of LPS, rabbits were killed with an overdose of T61 (Hoescht). A total of 14 rabbits was used, divided equally between treatment and control groups.

\section{Determination of indices of inflammation}

The numbers of leucocytes present in the CSF were determined by diluting CSF samples appropriately and then counting the leucocytes with a Sysmex cell counter (model CC-170M, TDA Corp., Kobe, Japan). TNF concentration was determined by bioassay with WEHI 164 cells as indicator cells, essentially as described previously, ${ }^{26}$ with human $\mathrm{TNF} \alpha$ (Boehringer Mannheim) as a standard. The limit of detection was $0.05 \mathrm{ng} / \mathrm{ml}$. CSF samples $(20 \mu \mathrm{l})$ were assayed in triplicate, the coefficient of variation was always $<21 \%$, and usually $<11 \%$. Glucose was measured enzymically with a commercially available kit (Boehringer Mannheim). Lactate was determined enzymically with lactate dehydrogenase, as described previously. ${ }^{27}$ The method of Lowry et al. ${ }^{28}$ was used to determine CSF protein content.

\section{Preparation of rabbit $T N F \alpha$ probe}

Based upon the published sequence of the rabbit TNF $\alpha$ cDNA, ${ }^{29}$ PCR primers TNF $\alpha-5$ (5'-ATGAGCACTGAGAGTATGATCC- $\left.3^{\prime}\right)$ and TNF $x-3$ (5'TTCATGCCGTTGGCCAGCA- $3^{\prime}$ ) were designed which spanned the precursor and part of the mature peptide cDNA sequences and would yield a PCR fragment of $355 \mathrm{bp}$. A PCR fragment was generated from rabbit spleen cDNA as follows. Rabbit spleen total RNA was prepared by an acid phenol extraction method essentially as described previously. ${ }^{30}$ Singlestranded cDNA was prepared from $100 \mu \mathrm{g}$ total RNA in a volume of $100 \mu \mathrm{l}$ with the following additions: oligo-dT $(12-17)$ (Pharmacia) $0.02 \mathrm{mg} / \mathrm{ml}, \quad$ RNAsin (Promega) 40 units, $1 \mathrm{~mm}$ dNTPs (Pharmacia), Moloney Murine Leukemia virus reverse transcriptase (BRL) 800 units, $10 \mathrm{~mm}$ DTT, $3 \mathrm{~mm} \mathrm{MgCl}_{2}, 75 \mathrm{mM}$ $\mathrm{KCl}$ and $50 \mathrm{~mm}$ Tris- $\mathrm{HCl}, \mathrm{pH} 8 \cdot 3$, and incubated at $37^{\circ} \mathrm{C}$ for $50 \mathrm{~min}$. PCR amplification was performed according to Zwickl et al. ${ }^{31}$ in $10 \mathrm{~mm}$ Tris- $\mathrm{HCl}, \mathrm{pH} 8 \cdot 3$, $1.5 \mathrm{~mm} \mathrm{MgCl}_{2}, 1 \mathrm{~mm}$ mercaptoethanol, Tween 20 $0.05 \% \mathrm{w} / \mathrm{v}, \mathrm{NP}-400.05 \% \mathrm{w} / \mathrm{v}$, in the presence of $40 \mathrm{~mm}$ dNTPs, $100 \mathrm{pmol}$ of each primer, Taq polymerase (Perkin-Elmer Cetus) 5 units, with $5 \mu$ of the single-stranded cDNA reaction as a template. The following PCR protocol was used: (1) $92^{\circ} \mathrm{C} / 1 \mathrm{~min}$, (2) $92^{\circ} \mathrm{C} / 15 \mathrm{~s}, 64^{\circ} \mathrm{C} / 1 \mathrm{~min}, 72^{\circ} \mathrm{C} / 1 \mathrm{~min}$, for 2 cycles, (3) $92^{\circ} \mathrm{C} / 15 \mathrm{~s}, 62^{\circ} \mathrm{C} / 1 \mathrm{~min}, 72^{\circ} \mathrm{C} / 1 \mathrm{~min}$, for 2 cycles, (4) $92^{\circ} \mathrm{C} / 15 \mathrm{~s}, 60^{\circ} \mathrm{C} / 1 \mathrm{~min}, 72^{\circ} \mathrm{C} / 1 \mathrm{~min}$, for 2 cycles, (5) $92^{\circ} \mathrm{C} / 15 \mathrm{~s}, 58^{\circ} \mathrm{C} / 1 \mathrm{~min}, 72^{\circ} \mathrm{C} / 1 \mathrm{~min}$, for 2 cycles, (6) $92^{\circ} \mathrm{C} / 15 \mathrm{~s}, 56^{\circ} \mathrm{C} / 1 \mathrm{~min}, 72^{\circ} \mathrm{C} / 1 \mathrm{~min}$, for 2 cycles, (7) $92^{\circ} \mathrm{C} / 15 \mathrm{~s}, 54^{\circ} \mathrm{C} / 1 \mathrm{~min}, 72^{\circ} \mathrm{C} / 1 \mathrm{~min}$, for 2 cycles and 
(8) $92^{\circ} \mathrm{C} / 15 \mathrm{~s}, 52^{\circ} \mathrm{C} / 1 \mathrm{~min}, 72^{\circ} \mathrm{C} / 1 \mathrm{~min}$, for 20 cycles on a thermal reactor (Hybaid).

The PCR product was purified on an agarose $0.8 \%$ Tris-borate-EDTA gel and the 5 -ends of the fragment were kinased in a $30-\mu \mathrm{l}$ volume containing polynucleotide kinase (New England Biolabs), 10 units, $1 \mathrm{~mm}$ ATP, $5 \mathrm{~mm}$ DTT, $10 \mathrm{~mm} \mathrm{MgCl}_{2}, 70 \mathrm{~mm}$ Tris$\mathrm{HCl}, \mathrm{pH} 7.6$, for $60 \mathrm{~min}$ at $37^{\circ} \mathrm{C}$. The kinased fragment was then ligated into the HindII site of plasmid $\mathrm{pBluescript;} \mathrm{the} \mathrm{plasmid} \mathrm{was} \mathrm{prepared} \mathrm{and} \mathrm{the} \mathrm{insert}$ sequenced according to standard procedures. ${ }^{32}$ The sequence of this PCR fragment was found to be completely homologous to the published sequence. ${ }^{29}$ To obtain a fragment for use as a probe, the plasmid was amplified in the E. coli strain DH5 $\alpha$ and insert DNA was prepared by $X h o \mathrm{I} / E c o$ RI digestion and agarose gel purification. ${ }^{32}{ }^{32} \mathrm{Phosphate}-\mathrm{labelled}$ rabbit TNF- $\alpha$ probe was generated by the random prime labelling method (Boehringer Mannheim).

\section{Determination of TNF $M R N A$ in brain tissue}

To evaluate the effects of dexamethasone treatment of meningitis on the levels of TNF $\alpha$ mRNA within brain tissue, brains were obtained from the following groups of animals: (1) rabbits without meningitis and killed $6 \mathrm{~h}$ after the induction of anaesthesia; (2) rabbits receiving LPS $2.5 \mathrm{ng}$ intra-cisternally at $0 \mathrm{~h}$ and killed at $6 \mathrm{~h}$; (3) rabbits receiving LPS $2.5 \mathrm{ng}$ intra-cisternally at $0 \mathrm{~h}$, saline i.v. at $5.75 \mathrm{~h}$, LPS $25 \mathrm{ng}$ intra-cisternally at $6 \mathrm{~h}$ and killed at $7 \mathrm{~h}$; and (4) rabbits receiving LPS $2.5 \mathrm{ng}$ intra-cisternally at $0 \mathrm{~h}$, dexamethasone $1.5 \mathrm{mg} / \mathrm{kg}$ i.v. at $5.75 \mathrm{~h}$, LPS $25 \mathrm{ng}$ intra-cisternally at $6 \mathrm{~h}$, and killed at $7 \mathrm{~h}$. Rabbits were killed with T61 and the brains were removed rapidly and frozen by immersion in liquid nitrogen. No attempt was made to remove blood from the tissue. Total RNA was extracted from the tissue by use of guanidine isothiocyanate-phenol-chloroform, essentially as described previously.$^{30}$ RNA (20 $\mu$ g) was blotted on to Zeta-probe membranes (BioRad) and probed with the rabbit TNF $\alpha$, and subsequently exposed to X-ray film. The intensity of the radio-active signals present on the blots was measured by the use of a phosphorimager (Molecular Dynamics). Control hybridisation for the amount of RNA loaded in each slot was by probing for a constitutively expressed mRNA, the eukaryotic protein synthesis initiation factor gene $e l F-4 A ;^{33}$ the probe for $e l F-4 A$ was radiolabelled by the random prime method (Boehringer Mannheim). The densities of TNF $\alpha$ mRNA were corrected for RNA loading based upon the corresponding density of the $e l F-4 A$ signal.

\section{Statistical analyses}

At each time point, dexamethasone-treated rabbits were compared to saline treated-controls by use of $t$ tests. Correlations were determined by the Spearman Rank Correlation coefficient. All data are expressed as mean value and standard error of the mean (SEM).

\section{Results}

\section{Characteristics of LPS-induced meningitis}

Intra-cisternal injection of $2.5 \mathrm{ng}$ of LPS induced a marked increase in CSF leucocytes of which $>95 \%$ were neutrophils $2 \mathrm{~h}$ after the injection, with a peak response occurring at $4 \mathrm{~h}$ (3171 SEM 551/ $\mu \mathrm{l}$ of CSF; fig. 1a), which declined slightly by $6 \mathrm{~h}$. Preliminary experiments demonstrated that the numbers of CSF leucocytes continued to decline, but remained raised at $12 \mathrm{~h}$ after LPS injection (data not shown). Pleocytosis was preceded by a peak of TNF activity (fig. 1b; 11.6 SEM $2.1 \mathrm{ng} / \mathrm{ml}$ of CSF) at $2 \mathrm{~h}$; the TNF levels were still raised at $6 \mathrm{~h}(0.11 \mathrm{SEM} 0.03 \mathrm{ng} / \mathrm{ml})$, whereas normal rabbit CSF $(0 \mathrm{~h})$ or CSF obtained from anaesthetised, non-meningitic rabbits $6 \mathrm{~h}$ after anaesthesia, contained $<0.05 \mathrm{ng}$ of $\mathrm{TNF} / \mathrm{ml}$ of $\mathrm{CSF}$. The TNF levels at $2 \mathrm{~h}$ strongly correlated with the magnitude of leucocyte influx at 4 or $6 \mathrm{~h}(\mathrm{p}<0.001)$.

Protein levels rose dramatically after LPS injection (fig. 1c) to reach a maximum of 1.5 SEM $0.2 \mathrm{mg} / \mathrm{ml}$ of CSF compared to values of 0.5 SEM $0.02 \mathrm{mg} / \mathrm{ml}$ of CSF at time 0 . CSF glucose levels (fig. 1d) rose only slightly from 6.0 SEM $0.2 \mathrm{mM}$ at time zero to 6.9 SEM $0.2 \mathrm{mM}$ at $6 \mathrm{~h}$. After LPS injection, CSF lactate rose from $18.5 \mathrm{SEM} 0.8 \mathrm{mg} / \mathrm{dl}$ of CSF to $50.4 \mathrm{SEM}$ $4.6 \mathrm{mg} / \mathrm{dl}$ at $6 \mathrm{~h}$, approximately a $2 \cdot 5$-fold increase (not shown).

A second intra-cisternal injection of LPS ( $25 \mathrm{ng} 6 \mathrm{~h}$ after the first injection) induced a pronounced rise in leucocyte levels above that present at the time of injection (fig. 1a); the peak level (6057 SEM 1002 leukocytes $/ \mu \mathrm{l}$ of CSF) occurred at $8 \mathrm{~h}$. At $12 \mathrm{~h}$, the leucocyte levels had declined to those present at the time of the second LPS injection (2917 SEM 383 leucocytes $/ \mu$ l of CSF). TNF (fig. 1b) was elevated $8 \mathrm{~h}$ after the first LPS injection (9.38 SEM $3.31 \mathrm{ng} / \mathrm{ml}$ of $\mathrm{CSF}$ ), and although the levels tended to be lower than that at $2 \mathrm{~h}$, this was not statistically different. Subsequently, TNF levels in CSF declined, but remained detectable at $12 \mathrm{~h}(0.15$ SEM $0.03 \mathrm{ng} / \mathrm{ml})$. The TNF levels at $8 \mathrm{~h}$ did not correlate with the leucocyte levels. Furthermore, the CSF TNF concentration at $2 \mathrm{~h}$ did not significantly correlate with the level at $8 \mathrm{~h}$. No statistically significant increase in CSF protein levels occurred after the second LPS injection (fig. lc), but rather the CSF protein content declined after $8 \mathrm{~h}$. Glucose (fig. 1d) levels remained essentially unchanged despite the introduction of more LPS into the CSF. Lactate levels rose slightly to 57.5 SEM $4.9 \mathrm{mg} / \mathrm{dl}$ of CSF at $8 \mathrm{~h}$, but then slowly declined to 48.4 SEM $3.6 \mathrm{mg} / \mathrm{dl}$ of CSF at $12 \mathrm{~h}$.

\section{Effect of dexamethasone on indices of meningitis following a second LPS injection}

Preliminary experiments (data not shown) demonstrated that treatment with dexamethasone $1.5 \mathrm{mg} / \mathrm{kg} 1 \mathrm{~h}$ before the intra-cisternal injection of LPS $25 \mathrm{ng}$ dramatically reduced the peak pleocytosis 


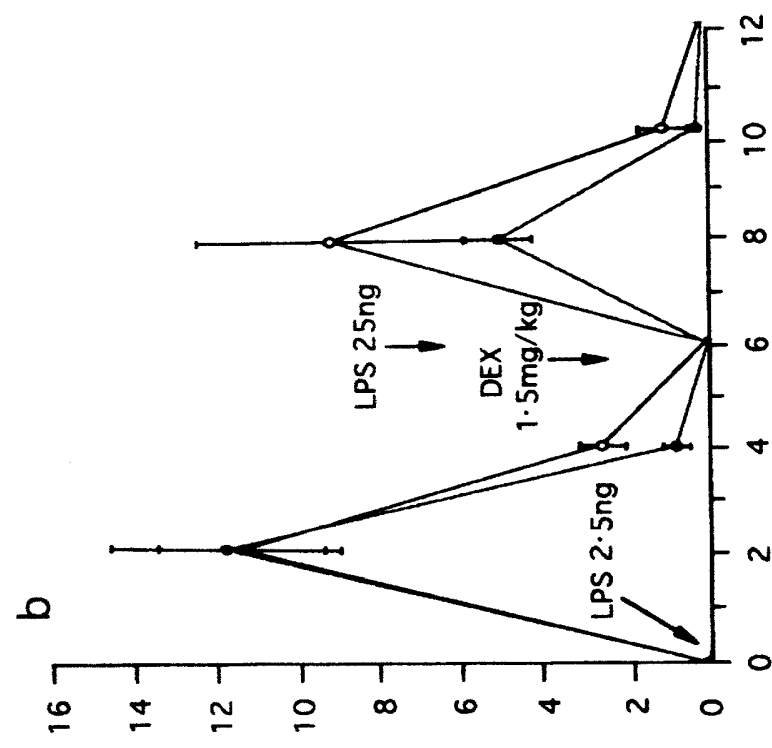

$\unlhd S \supset$ to $\mu m / 6 u \quad f N \perp$

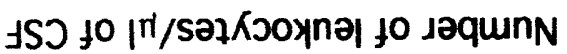

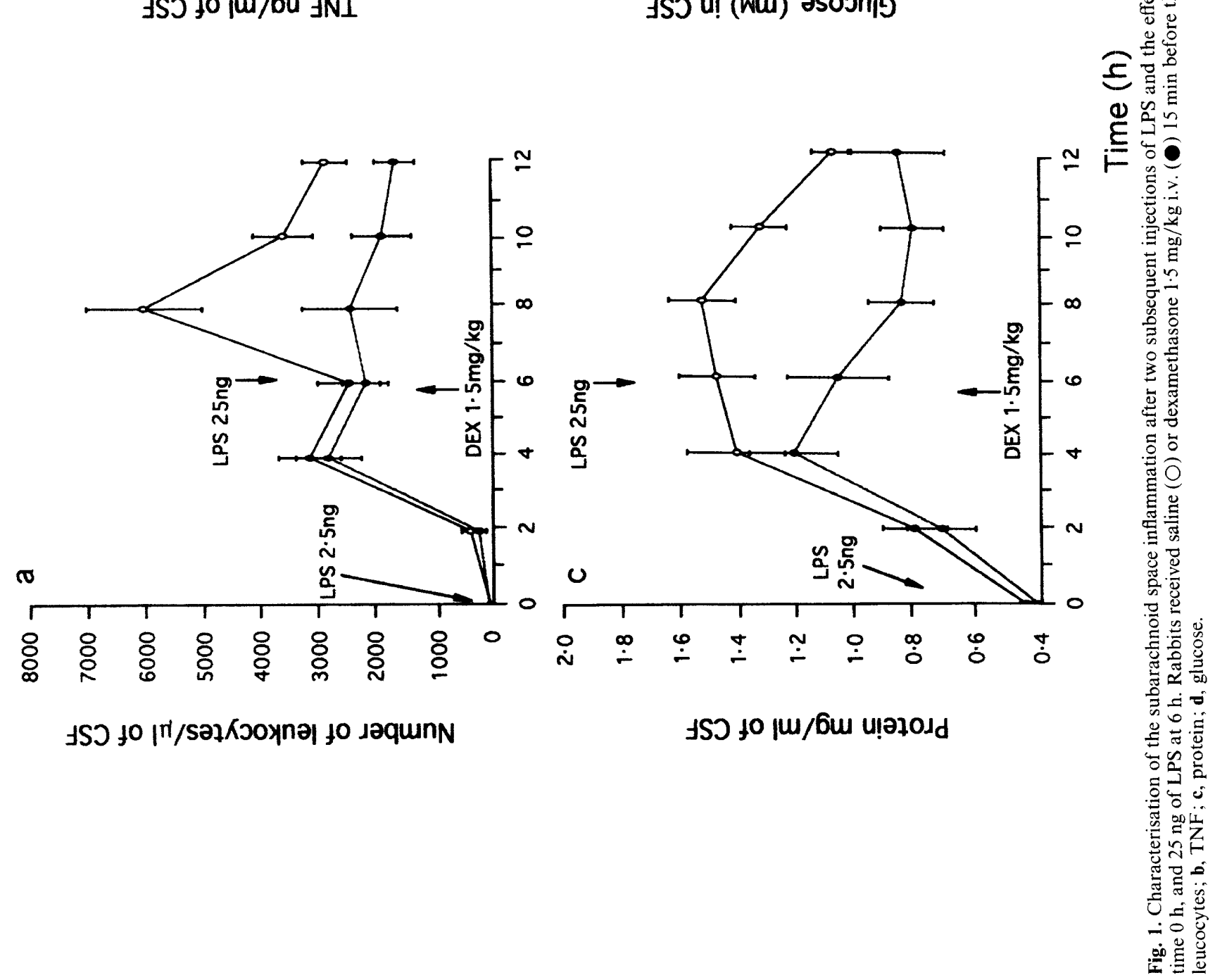

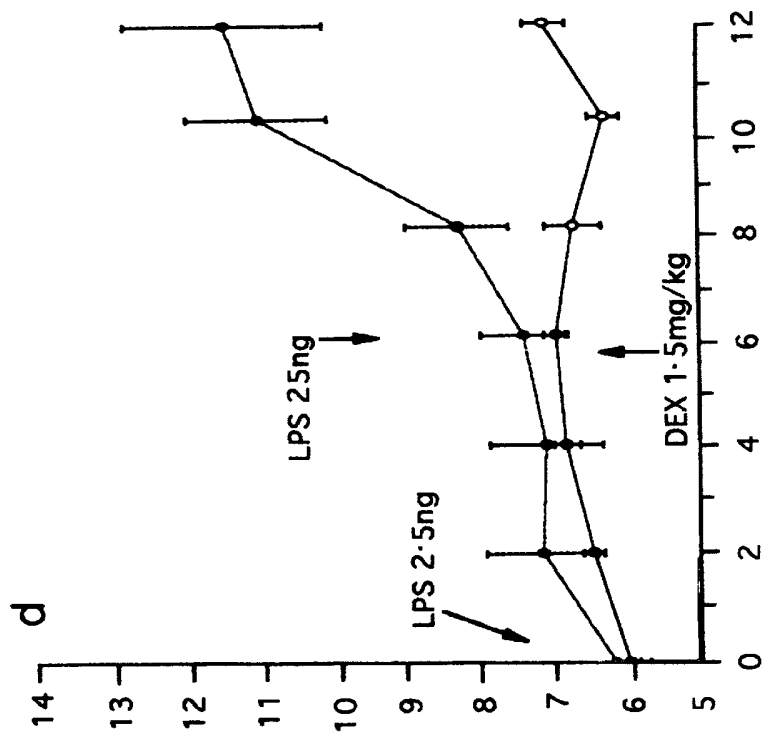

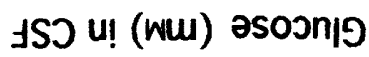

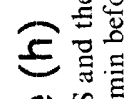

$\Phi$ 的

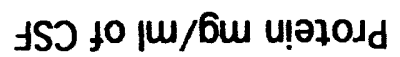

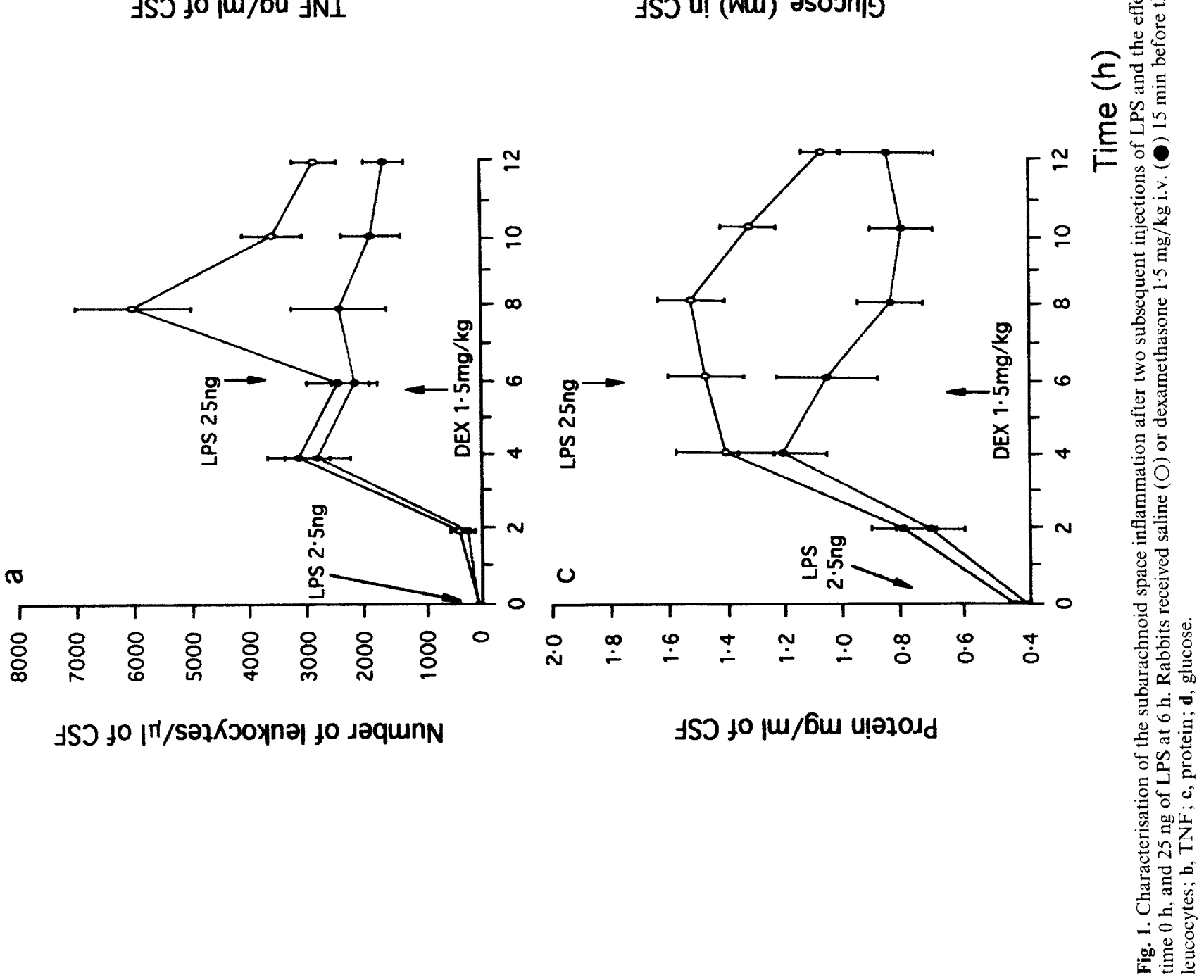




\section{elF-4A TNF}

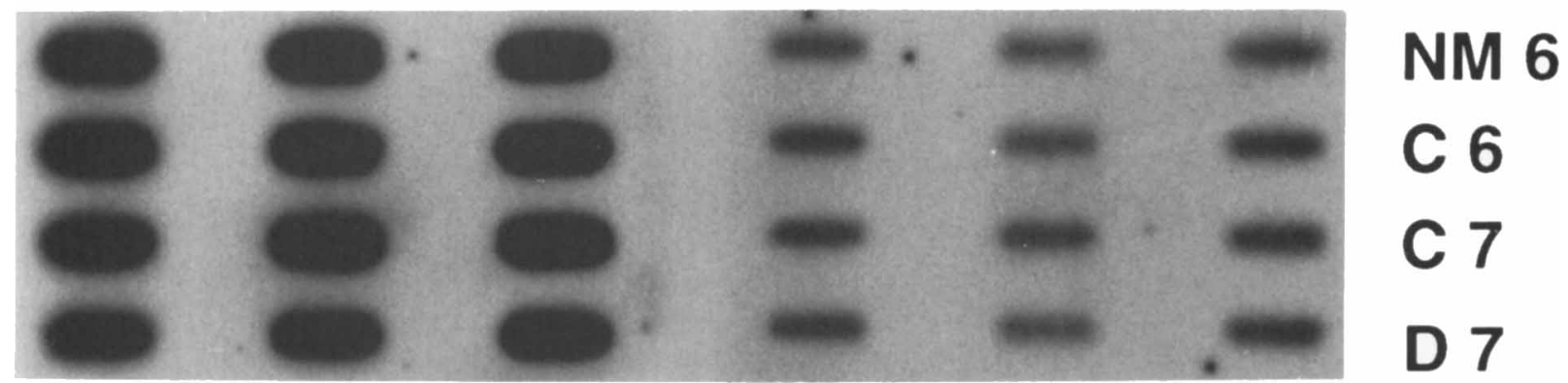

Fig. 2. Effect of dexamethasone treatment on brain TNF $\alpha$ mRNA levels. Rabbits (3/group) were administered $2 \cdot 5$ ng of LPS or saline intracisternally at $0 \mathrm{~h}$. Brains from non-meningitic animals (NM6) were removed $6 \mathrm{~h}$ after saline injection. Untreated control animals received saline $5.75 \mathrm{~h}$ after the LPS and brains were removed at $6 \mathrm{~h}(\mathrm{C} 6)$ or at $7 \mathrm{~h}(\mathrm{C} 7)$ after a second LPS injection at $6 \mathrm{~h}$. Dexamethasone-treated rabbits (D7) received $1.5 \mathrm{mg} / \mathrm{kg}$ of dexamethasone at $5.75 \mathrm{~h}$ and $25 \mathrm{ng}$ of LPS at $6 \mathrm{~h}$ and the brains were removed at $7 \mathrm{~h}$. Total RNA was extracted from the brains with guanidine thiocyanate-phenol-chloroform, and subsequently blotted and probed for mRNA specific for TNF $\alpha$ or $e l F-4 A$.

occurring $6 \mathrm{~h}$ after LPS injection (control rabbits 6934 SEM 569; dexamethasone-treated rabbits 366 SEM 157 leucocytes/ $\mu$ l of CSF; $\mathrm{n}=4$ /group; $p<0.01$ ), indicating that this dose of dexamethasone was indeed sufficient to inhibit CSF inflammation.

Despite the presence of marked inflammation within the subarachnoid space, this dose of dexamethasone $(1.5 \mathrm{mg} / \mathrm{kg}$ administered i.v. $15 \mathrm{~min}$ before the second LPS injection) inhibited the further influx of leucocytes into the CSF in response to a second injection of LPS, so that the leucocyte levels were significantly lower than those in untreated controls at 8,10 and $12 \mathrm{~h}$ after LPS injection $(p<0.05)$ (fig. 1a). Dexamethasone treatment reduced the magnitude of TNF activity from 9.38 SEM 3.31 in controls to 5.22 SEM $0.83 \mathrm{ng} / \mathrm{ml}$ of CSF at $8 \mathrm{~h}(\mathrm{p}=0.04)$, but the subsequent levels were not different from controls (fig. 1b). Similar effects on leucocyte influx and TNF accumulation were obtained when dexamethasone was administered $1 \mathrm{~h}$ before the second LPS injection (data not shown).

Administration of dexamethasone $1.5 \mathrm{mg} / \mathrm{kg}$ $15 \mathrm{~min}$ before the second LPS dose apparently reduced the CSF protein concentration immediately, but this was not significantly different from the concentration at $4 \mathrm{~h}$. Dexamethasone treatment reduced the CSF protein concentration compared to controls at 8 and $10 \mathrm{~h}$ (fig. $1 \mathrm{c} ; \mathrm{p}<0.004$ ), but there was no difference between the groups at $12 \mathrm{~h}$. Whereas dexamethasone treatment had no effect on CSF lactate levels compared to controls (data not shown), it dramatically increased the CSF glucose content (fig. 1d) at 10 and $12 \mathrm{~h}$ compared to controls $(\mathrm{p}<0.004)$.

\section{Effect of dexamethasone treatment on brain TNF $\alpha$ $m R N A$ levels}

On the basis of the previous results, rabbits were given LPS $2.5 \mathrm{ng}$ intra-cisternally and then were killed at $6 \mathrm{~h}$, or killed at $7 \mathrm{~h}$ after i.v. administration of saline or dexamethasone at $5.75 \mathrm{~h}$ and LPS $25 \mathrm{ng}$ intracisternally at $6 \mathrm{~h}$. In all cases, the total RNA extracted from the brains was used to determine the levels of mRNA specific for TNF $\alpha$. Similarly, total RNA was extracted from the brains of non-meningitic, anaesthetised rabbits killed $6 \mathrm{~h}$ after the intra-cisternal injection of saline; these animals did not have detectable CSF TNF $(<0.05 \mathrm{ng} / \mathrm{ml}$; data not shown). Quantitative determination by phosphorimaging indicated the intensity of the TNF $\alpha$ mRNA in brain (corrected for RNA loading based on the levels elF$4 A$, a constitutively expressed mRNA) to be 0.18 SEM 0.03 counts for brains from non-meningitic rabbits, 0.21 SEM 0.02 counts for rabbits killed at $6 \mathrm{~h}$ (before a second dose of LPS), and 0.18 SEM 0.03 counts for saline-treated and 0.25 SEM 0.05 counts for dexamethasone-treated rabbits killed $1 \mathrm{~h}$ after the second dose of LPS. Control experiments blotting different amounts of RNA demonstrated the phosphorimaging determinations for both TNF $\alpha$ and $e l F-4 A$ to be linear over about a 20 -fold range spanning the intensities of the presented data (data not shown). The levels of TNF $\alpha$ mRNA in brain were apparently not affected by LPS administration nor by dexamethasone therapy (fig. 2).

\section{Discussion}

The use of adjunct dexamethasone therapy in bacterial meningitis has demonstrated clinical benefit, especially when administered before antibiotics, ${ }^{9}$ which is in agreement with experimental studies. ${ }^{1}$ However, restriction in the number of clinical samples that can be obtained sequentially precludes analysis of early events after antibiotic administration. Although the early events can be examined experimentally, experimental studies demonstrating the efficacy of dexamethasone have either taken few samples late in the course of treatment ${ }^{34.35}$ or have initiated treatment early in the development of CSF inflammation, a situation that may not accurately reflect the established inflammation at clinical presentation..$^{2-7}$ Furthermore, 
the possibility that the cells within the subarachnoid space develop hyporesponsiveness towards LPS may obscure the activity of dexamethasone early in the course of treatment. We sought to expand the available experimental evidence to evaluate the value of dexamethasone in a model mimicking antibiotic-induced enhancement of an established level of subarachnoid space inflammation. To accomplish this, two sequential intra-cisternal injections of LPS were administered to rabbits and the efficacy of dexamethasone in reducing secondary inflammation was examined.

A low dose of intra-cisternally administered LPS $(2.5 \mathrm{ng})$ produced a distinct inflammatory response of c. 3000 leucocytes / $\mu$ l of CSF that was preceded by the appearance in the CSF of levels of TNF that correlated with the extent of pleocytosis occurring 4-6 $\mathrm{h}$ after the injection of LPS. Despite a rapid reduction in TNF levels, it was still detectable within the CSF $6 \mathrm{~h}$ later at the time of the second injection of LPS (25 ng), a situation similar to that observed at clinical presentation of meningitis. ${ }^{2.5711 .12}$ This measure of inflammation was apparently greater than that observed in some previous experimental studies evaluating dexamethasone. ${ }^{36.37}$

A second injection of LPS caused a further influx of leucocytes and release of TNF. This release of TNF is in apparent contrast to previous studies that demonstrated the development of a systemic LPShyporesponsive state in that TNF was not released after a second injection of LPS was administered i.v. to rabbits; ${ }^{22}$ although apparently insufficient to induce release of TNF, a low i.v. LPS dose (200 ng) was able to block TNF release when a second i.v. LPS dose (10000 ng) was given $6 \mathrm{~h}$ later. ${ }^{22}$ In the present study, although the TNF peak in CSF in response to the second injection of LPS was, perhaps, slightly attenuated-particularly in view of the 10 -fold increase in LPS stimulus - these results suggest that the development of tolerance to LPS is not as marked within the subarachnoid compartment as in the systemic circulation. TNF appears to be produced locally within the subarachnoid space s.38 $^{36.38}$ and circulating TNF levels appear to have little influence on CSF pleocytosis. ${ }^{39}$ The potential sources of locally produced TNF within the subarachnoid space include astrocytes, ${ }^{40+2}$ microglial cells, ${ }^{43}$ ependymal cells ${ }^{44}$ and, possibly, vascular tíssue.$^{45}$ However, the capacity of these cell types to display hyporesponsiveness to LPS apparently is yet to be determined.

In the present study, the evaluation of adjunct antiinflammatory therapy was based on the design of a clinical study ${ }^{9}$ that used dexamethasone administration before antibiotic treatment. Therefore, dexamethasone was present in the circulation for only a short time before the second intra-cisternal administration of LPS, but it still inhibited additional leucocyte influx, reduced secondary TNF release, led to a more rapid decrease in CSF protein content, and to an increase in CSF glucose concentration. However, it is noteworthy that a complete inhibition of TNF release did not occur with dexamethasone; the second TNF peak was $c .44 \%$ of the first peak. This lack of complex inhibition of TNF release is apparently not due to an insufficient time of exposure of target cells to dexamethasone, because administration of dexamethasone $1 \mathrm{~h}$ before the second dose of LPS resulted in similar findings in that the second TNF peak was $c$. $45 \%$ of the first (data not shown).

According to some, ${ }^{4-48}$ but not all ${ }^{49}$ studies, TNF is apparently chemotactic for neutrophils in vitro, and the intra-cisternal injection of TNF can induce subarachnoid space inflammation. ${ }^{39,50-53}$ However, the potency of intra-cisternal TNF is markedly less than that of IL-1, although these two cytokines can act synergically in this location, ${ }^{51.52}$ and the kinetics of leucocyte influx in response to intra-cisternal injection of TNF can be delayed, compared to that resulting from LPS injection, despite LPS inducing a rapid accumulation of TNF in the CSF that precedes leucocyte influx. ${ }^{51}$ These results, and other evidence indicating a dissociation of accumulation of TNF within the CSF and pleocytosis ${ }^{36.54}$ as a result of dexamethasone treatment, suggest that TNF may not be the primary mediator of cellular infiltration in meningitis, or at least that anti-inflammatory therapy can over-ride the chemotactic effects of TNF without inhibiting its release. Although the exact role of TNF in the induction of this largely ineffectual cellular influx, which may potentially result in damage to brain tissue from superoxide radical production or release of proteases from neutrophils, ${ }^{1}$ is unknown, TNF may also be directly damaging to the endothelia of the blood brain barrier ${ }^{2}$ and neural tissue owing to its cytotoxicity for oligodendrocytes ${ }^{42.55,56}$ and its capacity to induce demyelination of nerve fibres ${ }^{55}$ (for a review of the cytotoxic effects of cytokines on neural tissue see Morganti-Kossmann et al. $^{57}$ ).

Despite the release of TNF after the intra-cisternal administration of LPS, and reduction of TNF release by dexamethasone treatment, little change in TNF $\alpha$ mRNA occurred in the brain. Indeed, in the absence of detectable CSF TNF, rabbit brain contained easily detectable levels of TNF $\alpha$ mRNA; it has been demonstrated previously that normal animal tissues contain TNF $\propto$ mRNA. ${ }^{58}$ In-situ hybridisation has demonstrated that normal ependymal cells produce mRNA for $\mathrm{TNF} \alpha{ }^{44}$ Under certain conditions TNF $\alpha$ mRNA may have a short half-life $(<20 \mathrm{~min}) .{ }^{59,60}$ Given that the sampling times in the present study were not frequent, it is conceivable that a small change in TNF $\alpha$, mRNA could have occurred in response to secondary LPS injection and was not detected. However, previous in-vitro ${ }^{22}$ and in-vivo ${ }^{61}$ evidence suggests that the level of TNF $\alpha$ mRNA changes little in response to secondary stimulation with LPS, but this lack of response may be overcome by high concentrations of LPS relative to the primary dose. ${ }^{22}$ Furthermore, TNF $\alpha$ mRNA levels do not change in response to dexamethasone once cellular activation by LPS has begun. ${ }^{61}$ The activity of dexamethasone in 
attenuating TNF $\propto$ production in response to LPS has been proposed to be more at the level of translation of a pre-formed pool of TNF $\alpha$ mRNA, rather than inhibition of transcription ${ }^{61,62}$ However, data from this study cannot exclude the fact that certain cell types were showing changes in TNF $\alpha$ mRNA. Ependymal cells of the choroid plexus and ventricles, and to a lesser extent capillary endothelium and glial cells, but not other neural cell types, have been shown by immunocytochemical techniques to produce TNF, but only ependymal cells were reported to produce TNF $\alpha$ mRNA. ${ }^{44}$

Low CSF glucose content is associated with poor prognosis of meningitic children. ${ }^{63}$ The lack of reduction in CSF glucose concentration during experimental bacterial meningitis ${ }^{64}$ does not accurately reflect the disease in man. ${ }^{9-12}$ However, in the present study, and a previous experimental one, ${ }^{54}$ administration of dexamethasone resulted in a marked increase in CSF glucose content, which reflects clinical experience. ${ }^{9-12}$ In the present study, the rise in the CSF glucose content induced by dexamethasone occurred without changes in the CSF lactate content, again reflecting clinical experience ${ }^{9-12}$ particularly at $12 \mathrm{~h}$ after treatment. ${ }^{9}$ Dexamethasone is a synthetic adrenocortical steroid of the gluconeogenic type, and this class of compounds stimulates gluconeogenesis, but little attention has been paid to this facet of its activity

\section{References}

1. Tunkel AR, Scheld WM. Pathogenesis and pathophysiology of bacterial meningitis. Clin Microbiol Rev 1993; 6: 118-136.

2. Sharief MK, Ciardi M, Thompson EJ. Blood-brain barrier damage in patients with bacterial meningitis: association with tumour necrosis factor- $\alpha$ but not interleukin- $1 \beta$. $J$ Infect Dis 1992; 166: 350-358.

3. Chavanet $\mathrm{P}$, Bonnotte $\mathrm{B}$, Guiguet $\mathrm{M}$ et al. High concentrations of intrathecal interleukin-6 in human bacterial and nonbacterial meningitis. J Infect Dis 1992; 166: 428-431.

4. Mertsola J, Kennedy WA, Waagner D et al. Endotoxin concentrations in cerebrospinal fluid correlate with clinical severity and neurologic outcome of Haemophilus influenzae type b meningitis. Am J Dis Child 1991; 145: 1099-1103.

5. Arditi M, Manogue KR, Caplan M, Yogev R. Cerebrospinal fluid cachetin/tumor necrosis factor- $\alpha$ and platelet-activating factor concentrations and severity of bacterial meningitis in children. J Infect Dis 1990; 162: 139-147.

6. Mustafa MM, Level MH, Ramilo $\mathrm{O}$ et al. Correlation of interleukin- $1 \beta$ and cachectin concentrations in cerebrospinal fluid and outcome from bacterial meningitis. $J$ Pediatr 1989; 115: 208-213.

7. Mustafa MM, Ramilo O, Sáez-Llorens X, Olsen KD, Magness RR, McCracken GH. Cerebrospinal fluid prostaglandins, interleukin $1 \beta$ and tumor necrosis factor in bacterial meningitis. Clinical and laboratory correlations in placebotreated and dexamethasone-treated patients. Am $J$ Dis Child 1990; 144: 883-887.

8. Kennedy WA, Hoyt MJ, McCracken GH. The role of corticosteroid therapy in children with pneumococcal meningitis. Am J Dis Child 1991; 145: 1374-1378.

9. Odio CM, Faingezicht I, Paris M et al. The beneficial effects of early dexamethasone administration in infants and children with bacterial meningitis. $N$ Engl $J$ Med 1991; 324: $1525-1531$.

10. Girgis NI, Farid Z, Mikhail IA, Farrag I, Sultan Y, Kilpatrick ME. Dexamethasone treatment for bacterial meningitis in children and adults. Pediatr Infect Dis $J$ 1989; 8: 848-851.

11. Lebel MH, Hoyt J, Waagner DC, Rollins NK, Finitzo T, McCracken GH. Magnetic resonance imaging and dexa- during the treatment of meningitis. Although further research is necessary, it is tempting to speculate that one of the major benefits of adjunct dexamethasone therapy is early restoration of CSF glucose levels, which may ultimately contribute to reduction in neurological sequelae. However, during meningitis, anaerobic glycolysis within brain tissues appears to be operative $^{65}$ and the effects of rapidly elevated CSF glucose levels on brain physiology during meningitis remain unknown.

In clinical studies, CSF samples have been taken upon admission and 18-24 $\mathrm{h}$ after antibiotic or antibiotic plus anti-inflammatory therapy, and analysis of these samples has documented the benefit of dexamethasone in reducing several parameters of inflammation. ${ }^{7-12}$ If the results presented here are truly representative of the clinical situation, the rapid, transient influx of leucocytes and production of TNF induced by a second LPS injection and the attenuation of this by dexamethasone, may indicate possible immediate benefits of dexamethasone treatment that are obscured from clinical observation because of the required infrequency of CSF sampling. However, the impact of reduction of this transient increase in inflammation on the development of sequelae remains uncertain.

We thank Dr G. McMaster for providing the $e l F-4 A$ probe.

methasone therapy for bacterial meningitis. Am J Dis Child 1988; 143: 301-306.

12. Level MH, Freij BJ, Syrogiannopoulos GA et al. Dexamethasone therapy for bacterial meningitis. Results of two double-blind, placebo controlled trials. $N$ Engl J Med 1988; 319: 964-971.

13. McGowan JE, Chesney PJ, Crossley KB, LaForce FM. Guidelines for the use of systemic glucocorticosteroids in the management of selected infections. $J$ Infect Dis 1992; 165: $1-13$.

14. Tarlow MJ. Adjunct therapy in bacterial meningitis. $J$ Antimicrob Chemother 1991; 28: 329-332.

15. American Academy of Pediatrics. Committee on Infectious Diseases. Dexamethasone therapy for bacterial meningitis in infants and children. Pediatrics 1990; 86: 130-133.

16. Kaplan SL. Corticosteroids and bacterial meningitis. Scand $J$ Infect Dis Suppl 1990; 73: 43-54.

17. Täuber MG, Sande MA. Dexamethasone in bacterial meningitis: increasing evidence for a beneficial effect. Pediatr Infect Dis $J 1989 ; 8$ : 842-844.

18. Havens PL, Wendelberger KJ, Hoffman GM, Lee MB, Chusid MJ. Corticosteroids as adjunctive therapy in bacterial meningitis. A meta-analysis of clinical trials. Am J Dis Child 1989; 143: 1051-1055.

19. Kaplan SL. Dexamethasone for children with bacterial meningitis. Should it be routine therapy? Am J Dis Child 1989; 143: 290-292.

20. Havens PL. Meta-analysis redux-steroids and meningitis revisited. West Med J 1992; 157: 84-86.

21. Geiman BJ, Smith AL. Dexamethasone and bacterial meningitis. A meta-analysis of randomized controlled trials. West Med J 1992; 157: 27-31.

22. Mathison JC, Virca GD, Wolfson E, Tobias PS, Glaser K, Ulevitch RJ. Adaptation to bacterial lipopolysaccharide controls lipopolysaccharide-induced tumor necrosis factor production in rabbit macrophages. $J$ Clin Invest $1990 ; 85$ : $1108-1118$.

23. Syrogiannopoulos GA, Hansen EJ, Erwin AL et al. Haemophilus influenzae type b lipooligosaccharide induces meningeal inflammation. $J$ Infect Dis $1988 ; 157: 237-244$.

24. Dacey RG, Sande MA. Effect of probenecid on cerebrospinal 
fluid concentrations of penicillin and cephalosporin derivatives. Antimicrob Agents Chemother 1974: 6 : 437-441.

25. Spector R. Lorenzo AV. Inhibition of penicillin transport from the cerebrospinal fluid after intra-cisternal inoculation of bacteria. J Clin Incest 1974; $54: 316-325$.

26. Espevik T, Nissen-Mever J. A highly sensitive cell line. WEHI 164 clone 13. for measuring cytotoxic factor/tumor necrosis factor from human monocytes. $J$ Immunol Methods 1986: 95: 99-105.

27. Tuomanen E, Tomasz A. Hengstler B. Zak O. The relative role of bacterial cell wall and capsule in the induction of infiammation in pneumococcal meningitis. $J$ Infect Dis $1985 ; 151: 535-540$.

28. Lowry OH, Rosebrough NJ. Farr AL. Randall RJ. Protein measurement with the folin phenol reagent. $J$ Biol Chem 1951: 193: 265-275.

29. Ito $\mathrm{H}$. Yamamoto $\mathrm{S}$. Kuroda $\mathrm{S}$ et al. Molecular cloning and expression in Escherichia coli of the cDNA coding for rabbit tumor necrosis factor. D.VA 1986: 5: 149-156.

30. Chomczynski P. Sacchi N. Single-step method of RNA isolation by acid guanidinium thiocyanate-phenol-chloroform extraction. Anal Biochem 1987: 162: 156-159.

31. Zwickl M. Zaninetta D. McMaster GK. Hardman N. Selective cloning of B cell hybridoma-specific rearranged immunoglobulin gene loci using the polymerase chain reaction. $J$ Immunol Methods 1990: 130: 49-55

32. Sambrook J. Fritsch EF. Maniatis T. Molecular cloning. A laboratory manual. 2nd edn. Cold Spring Harbor. Cold Spring Harbor Laboratory Press. 1989.

33. Nielson PJ. McMaster GK. Trachsel H. Cloning of eukaryotic protein synthesis initiation factor genes: isolation and characterization of cDNA clones encoding elF-4a. Nucleic Acids Res 1985: 13:6867-6880.

34. Kadurugamuwa JL. Hengstler B. Zak O. Cerebrospinal fluid protein profile in experimental pneumococcal meningitis and its alteration by ampicillin and anti-inflammatory agents. J Infect Dis 1989; 159: 26-34.

35. Syrogiannopoulos GA, Olsen KD. Reisch JS. McCracken GH. Dexamethasone in the treatment of experimental Haemophilus influenzae type b meningitis. J Infect Dis 1987: 155: 213-219

36. Mustafa MM, Ramilo O. Olsen KD et al. Tumor necrosis factor in mediating experimental Haemophilus influenzae type b meningitis. J Clin Incest 1989: 84: 1253-1259.

37. Sáez-Llorens X. Ramilo O. Mustafa MM et al. Pentoxifylline modulates meningeal inflammation in experimental bacterial meningitis. Antimicrob Agents Chemother 1990: 34: 837-843.

38. Waage A. Halstensen A. Shalaby R. Brandtzæg P. Kierulf P. Espevik $T$. Local production of tumor necrosis factor $\boldsymbol{x}$. interleukin 1 , and interleukin 6 in meningococcal meningitis. Relation to the inflammatory response. $J$ Exp Med 1989: 170: 1859-1867.

39. Kim KS, Wass CA. Cross AS, Opal SM. Modulation of bloodbrain barrier permeability by tumor necrosis factor and antibody to tumor necrosis factor in the rat. Lymphokine Citokine Res 1992: 11: 293-298.

40. Velasco S. Tarlow M. Olsen K. Shay JW. McCracken GH. Nisen PD. Temperature-dependent modulation of lipopolysaccharide-induced interleukin- $1 \beta$ and tumor necrosis factor $\alpha$ expression in cultured human astroglial cells by dexamethasone and indomethacin. J Clin Incest 1991: 87: 1674-1680.

41. Chung IY. Benveniste EN. Tumor necrosis factor- $x$ production by astrocytes. Induction by lipopolysaccharide. IFN- - and IL-1B. J Imminol 1990: 144: 2999-3007.

42. Robbins DS. Shirazi Y. Drysdale B-E. Lieberman A. Shin HS. Shin ML. Production of cytotoxic factor for oligodendrocytes by stimulated astrocytes. $J$ Immunol 1987 : 139: 2593-2597.

43. Chat CC. Hu S. Close Ket al. Cytokine release from microglia: differential inhibition by pentoxifylline and dexamethasone. J Infect Dis 1992: 166: 847-853.

44. Tarlow MJ. Jenkins R. Comis SD et al. Ependymal cells of the choroid plexus express tumour necrosis factor- $\alpha$. Neuropathol Appl Neurobiol 1993; 19: 324-328.
45. Warner SJC. Libby P. Human vascular smooth muscle cells. Target for and source of tumor necrosis factor. $J$ Immunol 1989: 142: 100-109.

46. Ming WJ. Bersani L, Mantovani A. Tumor necrosis factor is chemotactic for monocytes and polymorphonuclear leukocytes. J Immunol 1987: 138: 1469-1474.

47. Cybulsky MI. McComb DJ, Movat HZ. Neutrophil leukocyte emigration induced by endotoxin. Mediator roles of interleukin 1 and tumor necrosis factor $x$. J Immunol 1988; 140: $3144-3149$.

48. Mason MJ, Van Epps DE. In vivo neutrophil emigration in response to interleukin-1 and tumor necrosis factor-alpha. J Leukoc Biol 1989; 4: 62-68.

49. Shalaby MR. Palladino MA. Hirabayashi SE et al. Receptor binding and activation of polymorphonuclear neutrophils by tumor necrosis factor-alpha. $J$ Leukoc Biol $1987 ; 41$ : 196-204.

50. Saukkonen K. Sande S, Cioffe C et al. The role of cytokines in the generation of inflammation and tissue damage in experimental gram-positive meningitis. J Exp Med 1990: 171: $439-448$

51. Ramilo O. Sáez-Llorens X. Mertsola J et al. Tumor necrosis factor $\alpha /$ cachetin and interleukin $1 \beta$ initiate meningeal inflammation. J Exp Med 1990; 172: 497-507.

52. Quagliarello VJ. Wispelwey B. Long WJ, Scheld WM. Recombinant human interleukin-1 induces meningitis and blood-brain barrier injury in the rat. Characterization and comparison with tumor necrosis factor. J Clin Incest 1991: 87: $1360-1366$

53. Boccazzi A. Erroi A, Mantegazza M, Bellosta C, Ghezzi P. TNF and IL-1 in a rabbit model of meningitis. Int $J$ Immunopathol Pharmacol 1993; 6: 85-91.

54. Mustafa MM, Ramilo O, Mertsola J et al. Modulation of inflammation and cachectin activity in relation to treatment of experimental Haemophilus influenzae type b meningitis. $J$ Infect Dis $1989 ; 160: 818-825$.

55. Selmja KW, Raine CS. Tumor necrosis factor mediates myelin and oligodendrocyte damage in vitro. Ann Neurol 1988; 23: $339-346$.

56. Selmja K. Raine CS, Fargooq M, Norton WT, Brosnan CF. Cytokine cytotoxicity against oligodendrocytes. Apoptosis induced by lymphotoxin. $J$ Immunol $1991 ; 147$ : 1522-1529.

57. Morganti-Kossmann MC, Kossmann T, Wahl SM. Cytokines and neuropathology. Trends Pharmacol Sci 1992; 13: 286-291.

58. Ulich TR, Guo KZ, Irwin B, Remick DG, Davatelis GN. Endotoxin-induced cytokine gene expression in vivo. 2. Regulation of tumor necrosis factor and interleukin-1 $\alpha / \beta$ expression and suppression. Am J Pathol 1990; 137: 1173-1185.

59. Remick DG, Strieter RM, Lynch JP, Nguyen D, Eskandari M, Kunkel SL. In vivo dynamics of murine tumor necrosis factor- $\alpha$ gene expression. Kinetics of dexamethasoneinduced suppression. Lab Invest $1989 ; 60: 766-771$.

60. Sariban E, Imamura K, Leubbers R, Kufe D. Transcriptional and posttranscriptional regulation of tumor necrosis factor gene expression in human monocytes. $J$ Clin Invest 1988 ; 81: $1506-1510$.

61. Beutler B. Krochin N, Milsark IW, Luedke C, Cerami A Control of cachectin (tumor necrosis factor) synthesis: mechanisms of endotoxin resistance. Science 1986; 232 977-980.

62. Han J. Thompson P, Beutler B. Dexamethasone and pentoxifylline inhibit endotoxin-induced cachectin/tumor necrosis factor synthesis at separate points in the signaling pathway. J Exp Med 1990; 172: 391-394.

63. Brooke Williams RD. Alterations in the glucose transport mechanism in patients with complications of bacterial meningitis. Pediatrics 1964; 34: 491-502.

64. Moxon ER, Smith AL, Averill DR. Brain carbohydrate metabolism during experimental Haemophilus influenzae meningitis. Pediatr Res 1979: 13: 52-59.

65. Guerra-Romero L, Täuber MG, Fournier MA, Tureen JH. Lactate and glucose concentrations in brain interstitial fluid. cerebrospinal fluid, and serum during experimental pneumococcal meningitis. J Infect Dis 1992; 166: 546-550. 